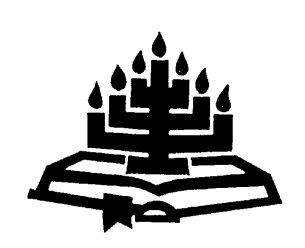

\title{
Paul's use of slavery imagery in the Hagar allegory
}

\author{
P. Balla
}

School of Ecclesiastical Science \& Ancient Languages

Potchefstroom Campus

North-West University

POTCHEFSTROOM

E-mail: balla.peter@kre.hu

\begin{abstract}
Paul's use of slavery imagery in the Hagar allegory

In this article it is examined how Paul used slavery imagery in Galatians 4 when dealing with the theme of God's "children". The use of words related to the semantic field of slavery in Galatians is briefly discussed. Paul uses these words both with their literal meaning and in a figurative sense. This is also true for the main passage to be discussed in this article - the Hagar allegory. In Galatians 4, Paul first speaks about a real slave woman, and then uses this imagery to describe those who do not accept God's promises to have been fulfilled in Jesus. The way Paul uses the term "allegorise" is examined. It is argued that in Galatians 4 Paul uses the slavery imagery in order to speak about aspects of one's relationship to God. The background of his use of the Hagar allegory is his "salvation historical" view concerning God's covenantal relationship to his people. He uses allusions to Old Testament texts to express his view regarding who belongs to God's people in the era of the new covenant.
\end{abstract}

\section{Opsomming}

\section{Paulus se gebruik van slawerny as beeld in die Hagar- allegorie}

In hierdie artikel word Paulus se gebruik van die slawerny-beeld in Galasiërs 4 ondersoek. Eers word ander woorde in Galasiërs uit die slawerny-betekenisveld kortliks bestudeer. Paulus gebruik hierdie woorde letterlik sowel as figuurlik. Dit geld ook van die deel van Galasiërs wat in hierdie artikel bespreek word, naamlik die Hagar-allegorie. In Galasiërs 4 praat Paulus eers van 'n werklike slavin, en dan gebruik hy dit as beeld om die- 
gene te beskryf wat nie aanvaar dat God se beloftes in Jesus vervul is nie. Die wyse waarop Paulus die term "allegoriseer" gebruik, word ook ondersoek. Die argument is dat Paulus in Galasiërs 4 slawerny as beeld gebruik om aspekte van 'n mens se verhouding met God te beskryf. Die agtergrond van sy gebruik van die Hagar-allegorie is sy openbaringshistoriese benadering van God se verbondsverhouding met sy volk. Met toespelings op Ou-Testamentiese gedeeltes gee hy uitdrukking aan sy beskouing oor wie deel uitmaak van die volk van God in die nuwe verbond.

\section{Introduction}

In this article, I would like to examine how Paul uses slavery imagery in Galatians 4, in his dealing with the theme of God's "children," that is, God's people. ${ }^{1}$ In Galatians, Paul uses slavery imagery in different ways: both in its literal (real) meaning referring to a relation in a household, and also in a figurative sense to express a relationship between God and human beings. This twofold usage is also true for chapter four of the letter. Thus, it may be helpful to briefly survey the use of words related to the semantic field of slavery in Galatians.

\section{The semantic field of slavery in Galatians}

The Greek word for slave, doulos, appears in Galatians four times. In Galatians 1:10b, Paul uses it in a figurative sense about his relationship to Jesus: $\mathbf{2}$ "If I were still pleasing people, I would not be a servant of Christ." It is significant that Paul uses the same noun also about real slaves in Galatians 3:28. There it stands in a list of pairs where "slaves" are mentioned with their counterparts, "free persons": "There is no longer Jew or Greek, there is no longer slave or free, there is no longer male and female; for all of you are one in Christ

1 This article was completed during my stay in April 2008 in Potchefstroom, while I was a visiting research scholar at the North-West University in South Africa. It was presented at a colloquium at the Faculty of Theology of the North-West University on 11 April, and then also at the conference of the New Testament Society of South Africa on 17 April, 2008. I thank the South African colleagues for their helpful comments on the manuscript, especially for those of my hosting professor, Fika Janse van Rensburg. The research on the background of the Hagar allegory was supported by the Alexander von Humboldt Foundation, who helped me with scholarships for short research visits in the summer of 2006 and 2007, when I worked on a commentary on Galatians at the University of Heidelberg in Germany.

2 Bible quotations are from the New Revised Standard Version (=NRSV). 
Jesus." Then in Galatians 4:1, 7 we have a usage very similar to that in the Hagar allegory, because at first real slaves are mentioned, then the Galatians are reminded that they are no longer slaves in a figurative sense (v. 1): "My point is this: heirs, as long as they are minors, are no better than slaves, though they are the owners of all the property"; (v. 7): "So you are no longer a slave but a child, and if a child then also an heir, through God."

We shall see that the main thrust of the argument in the Hagar allegory will be to convince the Galatians that through their faith in Jesus as the Son of God their relationship to God is not that of a slave to a master, but it is the relationship of a son to his/her father. I suggest that the aim of using doulos in the real, literal sense is to create a point of contact between Paul and his addressees, and to turn from this well-known, "common" meaning to a figurative sense in order to express the relationship between God and human beings.

Other words from the same word stem are used in Galatians in a figurative sense only. One of them, douleia, occurs in Galatians 4:24 and 5:1. Galatians 4:24 belongs directly to the Hagar passage. This verse reads: "Now this is an allegory: these women are two covenants. One woman, in fact, is Hagar, from mount Sinai, bearing children for slavery." Galatians 5:1 can be seen as a transitory verse drawing the conclusion from the Hagar allegory and leading on to the next passage. ${ }^{3}$ In this verse we read: "For freedom Christ has set us free. Stand firm, therefore, and do not submit again to a yoke of slavery."

The verb "to act as a slave, to be a slave" (douleuō), appears in Galatians only in a figurative sense. In Galatians 4:8, 9 we read: "Formerly, when you did not know God, you were enslaved to beings that by nature are not gods. Now, however, that you have come to know God, or rather to be known by God, how can you turn your back again to the weak and beggarly elemental spirits? How can you want to be enslaved to them again?" Galatians 4:25 is part of the Hagar passage: "Now Hagar is Mount Sinai in Arabia and corresponds to the present Jerusalem, for she is in slavery (literally: she is serving, douleuei) with her children." Then in Galatians 5:13 the word occurs in an ethical admonition: "For you were called to

3 Some scholars view Galatians $5: 1$ as the concluding verse of the Hagar allegory, e.g. Vouga (1998:113), Hays (2000:299), and Witherington (2004:321, 340 ) who treat the passage Galatians $4: 21-5: 1$ as one unit in their commentaries. 
freedom, brothers and sisters; only do not use your freedom as an opportunity for self-indulgence, but through love become slaves to one another." The causative douloo ("to make to serve") appears in Galatians only once (Gal. 4:3), and there with a figurative meaning: "So with us; while we were minors, we were enslaved (ēmetha dedoulömenoi) to the elemental spirits of the world." Neither the feminine doule nor the neuter doulon occurs in Galatians.

From the other main word stem in this semantic field, paid-, only two occur in Galatians. One of these Greek words is paidagogos (guardian), referring to the Mosaic law in Galatians 3:24, 25. These verses read: "Therefore the law was our disciplinarian until Christ came, so that we might be justified by faith. But now that faith has come, we are no longer subject to a disciplinarian." 4 The other Greek word from this word stem is paidiske ("slave woman"), which is a key term in our Hagar passage, appearing five times in Galatians 4:22-23: "For it is written that Abraham had two sons, one by a slave woman and the other by a free woman. One, the child of the slave, was born according to the flesh; the other, the child of the free woman, was born through the promise." In Galatians 4:30 it occurs twice: "But what does the Scripture say? 'Drive out the slave and her child, for the child of the slave will not share the inheritance with the child of the free woman'", and in Galatians 4:31, the concluding verse of the Hagar passage reads: "So then, friends, we are children, not of the slave but of the free woman."

We shall return to this word later. Here we simply note that the first four occurrences of the word "slave woman" refer to the real slave woman Hagar, whereas the last occurrence of the word at the end of the passage has a twofold meaning: whereas it does refer to Hagar, it nevertheless says about Paul and the Christ-believing Galatians that they are not descendants of Hagar in a spiritual sense. Thus, the word appears here also in a figurative sense. The terms pais, paidion, paideia and paideuō do not occur in Galatians.

4 For a discussion of the role of the "disciplinarian" or the "guardian", see Morris (1996:126-127). 
Table 1: The semantic uses of slavery imagery in Galatians

\begin{tabular}{|l|l|l|}
\hline & literal sense & figurative sense \\
\hline doulos & $3: 28 ; 4: 1$ & $1: 10 \mathrm{~b} ; 4: 7$ \\
douleia & & $4: 24 ; 5: 1$ \\
douleuōo & & $4: 8-9 ; 4: 25 ; 5: 13$ \\
douloō & & $4: 3$ \\
paidagōgos & & $3: 24-25$ \\
paidiskē & $4: 22-23 ; 4: 30$ (twice) & $4: 31$ \\
\hline
\end{tabular}

On the basis of Paul's use of the semantic field of slavery in Galatians, I suggest that in the Hagar passage Paul speaks about a real slave woman in order to use this imagery also in a figurative sense to describe those who do not accept God's promises to have been fulfilled in Jesus. Since the verb allegorise is a key term in the passage, let us briefly discuss the way in which Paul uses it in this context.

\section{The term allegorise}

The Bauer dictionary offers only one meaning for the verb allēgoreō (Bauer, 1979:39): "speak allegorically". The Greek verb appears only in Galatians 4:24 in the literature Bauer's dictionary covers (the New Testament, the Apostolic Fathers, and other early Christian literature; Bauer, 1979:xxix). Richard Longenecker (1990:208) notes that it "is a late Greek word not found in the LXX but appearing first in Philo (Cher. 25)". He rightly emphasises that "Paul's use of Scripture here ... differs from what we know of the allegorical treatments of the first-century Alexandrian Jew Philo" (Longenecker, 1990:209). Longenecker (1990:203-204) sums up Philo's views as follows:

For Philo, Hagar the handmaid symbolizes the preliminary learning that can be obtained in the schools ... Sarah, the mistress of the house, on the other hand, exemplifies virtue, and her offspring is true wisdom.

Longenecker (1990:208) argues that the term allēgoreo may be translated not only as "speak allegorically", but also as "interpret allegorically" and in Galatians 4:24 he opts for the latter meaning. He translates hatina estin allēgoroumena as "these things are [now] being interpreted allegorically" (Longenecker, 1990:198, where he translates the whole Hagar passage). He adds "now" in brackets to his translation, emphasising that here Paul did not necessarily think 
that the Old Testament text was intended to be understood allegorically (i.e. it did not "speak" allegorically), but it was Paul who applied the Old Testament text to his own day by "interpreting" it allegorically (Longenecker, 1990:208-209).

I accept this view of Longenecker. 5 In Galatians 4:24 the verb occurs in the form of a present passive participle. This suggests that it is Paul who treats the Old Testament text "in allegorical fashion" (Longenecker, 1990:210). Of course, it is possible that Paul was prompted to deal with these Old Testament passages concerning Abraham by the opponents who had also referred to him, but Paul uses a kind of allegorical interpretation to show that the various relationships in Abraham's family (including that of the slave woman) have a message to the addressees of Galatians (including the adversaries). ${ }^{6}$ I argue that in Galatians 4, Paul uses slavery imagery in order to speak about aspects of one's relationship to God. He uses allusions to Old Testament texts to express his view regarding who belongs to God's people in the era of the new covenant. Thus, the background of his use of the Hagar "allegory" is his "salvation historical" view, concerning God's covenantal relationship to his people. 7

I shall argue for this thesis by offering some exegetical remarks on the Hagar passage in Galatians 4. The whole text will not be exposed in all its details, rather the focus will be on the slavery imagery and the interpretation of its "message".

5 For further literature on "allegorising" in Paul, see e.g. Bruce (1982:217), Dunn (1993:247-248) and in greater detail, Witherington (2004:321-330).

Some scholars call for avoiding the label "false teachers," and simply suggest "missionaries", or "teachers", e.g. Martyn (1997:14) refers to them with a capital letter: "the Teachers". In this article I refer to them from the viewpoint of Paul. By doing so I do not attach any "value judgment" to my terminology; I simply present them as Paul's "opponents", or "adversaries". It shall be seen also in the Hagar passage that he viewed them as such. I note the view of Nanos (2002b; cf. also a volume edited by him, 2002a) which argues that the adversaries were not in any sense Christians, but they were of Jewish origin, and there were probably also proselytes among them. For a criticism of Nanos' view, see Carson and Moo (2005:465), with whom I agree.

$7 \quad$ For a detailed survey of scholarship against the notion of "salvation history" in the Bible, and for a proposed defence of it, see Yarbrough (2004). I cannot go into detail here, but I would argue that the Hagar allegory is an example of Paul's view concerning the history of God's relationship with his people and that we may continue to refer to this view as "salvation history" (or, as it is used by some scholars, "revelation history"). 


\section{The "message" of the Hagar allegory}

In what follows, it will be argued that Paul uses (and interprets allegorically) Old Testament texts in order to express his view concerning who belongs to God's people. By doing so, he uses a wellknown (and in his day wide-spread) social category - that of slavery; yet, he also uses the same imagery in a figurative way.

\subsection{The place of Galatians 4:21-31 in the structure of the letter}

Scholars usually agree that in his letters Paul uses structural elements that were known in the rhetorical practices of his day. However, there is some disagreement as to the classification of the Hagar passage. H.D. Betz, e.g. holds that this section still belongs to the probatio (as its sixth and last part; see Betz, 1988:21, 238).

Longenecker (1990:186) argues that because Galatians 4:12 contains the first imperative in the letter, the exhortatio begins with this verse. He regards the Hagar passage as the second part of the exhortation, in which there are four further imperatives - albeit in Old Testament quotations (Longenecker, 1990:199).

Perhaps, we do not have to decide in a rigid way. A "last argument" can just as well be a transition to the next main section. I hold that the Hagar allegory does have an argumentative function, although it concludes with a "call" (or indeed, with an exhortation) to "drive out the slave and her child" (v. 30). We may thus see and recognise an element of truth in both classifications. For this reason, I regard it as a transitory section aiming at convincing the addressees (in an argumentative fashion) and at the same time calling them to an appropriate action.

Galatians 4:21-31 continues with the argument posed in 4:1-7. In the first verses of Galatians 4 Paul argues that the heir is not different from a slave while the heir is a child (v. 1). As long as the addressees (indeed Paul as well, since he uses first person singular here) were "children", they were in slavery (v. 3). Here, in verse 1 , the slave is a "real" slave, $\mathbf{8}$ whereas previously Paul and the Galatians were in slavery in a figurative sense: they were under the law, they had to be redeemed from being under the law (v. 5; cf. Dunn,

8 Paul may have had the Roman family law in view here; see e.g. Dunn (1993:210). 
1993:217). Now the Galatians are no longer slaves (in a figurative sense), because they have accepted Jesus as God's Son (v. 4), and thus have become sons and heirs themselves (v. 7; cf. Morris, 1996:132).

\subsection{Exegetical remarks on Galatians 4:21-31}

\subsubsection{The significance of the names (or their absence) in the passage}

In verse 21 Paul uses the expression "under the law" (hypo nomon; see v. 4-5), and on the basis of verses 1-7, these words remind the addressees of their slave status in a figurative sense. He tells the Galatians that if they have such a high regard for the law, they should listen to its section on Hagar as well (v. 21): "Tell me, you who desire to be subject to the law, will you not listen to the law?"

Scholars debate as to who suggested the theme of Abraham or, indeed, the Hagar story to the Galatians. On the basis of a "mirror reading" it has been proposed that the adversaries referred to Abraham's example in their own support, and that is why Paul treats this passage, and interprets it to his own purposes (cf. Bruce, 1982:218; Longenecker, 1990:199). Whoever initiated the theme, in Galatians Paul uses it as an argument for what he wants to reach among the Galatians, so in the Hagar allegory the Old Testament passage becomes Paul's "text".

Paul uses Old Testament Scripture to support his own view. He does so among the Galatians - who were of non-Jewish origin (as they were not descendants of Isaac "according to the flesh"). Paul holds that the Old Testament Scripture is such an authority that he and even the non-Jewish Christian Galatian addressees have to listen to what it says. ${ }^{9}$ Even if it was the adversaries who initially argued on the basis of the Abraham passages, Paul also argues from Scripture - thereby showing that it is an authority for him as well as for Christians of non-Jewish origin. This is in agreement with the main thrust of the Hagar allegory, that is with Paul's argument that even the non-Jewish Christians become descendants of Isaac in a spiritual sense.

9 Here nomos probably refers to the Mosaic law, the Pentateuch; see e.g. Rohde (1989:193). 
In verse 22 Paul uses a formula that usually introduces a quotation from Scripture: gegraptai. ${ }^{10}$ In this verse we read: "For it is written that Abraham had two sons, one by a slave woman and the other by a free woman." Here the introductory formula is not followed by a direct quotation, but by a summary of two verses (from two different chapters) from the book of Genesis. In Genesis 16:15 we read: "Hagar bore Abram a son; and Abram named his son, whom Hagar bore, Ishmael." The name of Ishmael does not appear in Galatians, because it is Hagar whose name is important for Paul to mention, as his main emphasis lies on the contrast between the status of a "slave" and that of a "free" woman. In Genesis 21:2-3 we read: "Sarah conceived and bore Abraham a son in his old age, at the time of which God had spoken to him. Abraham gave the name Isaac to his son whom Sarah bore him." By mentioning Abraham and his sons, Paul prepares the way to elaborate on the theme of the covenant in Galatians 4:24 ff.

It is worth noting already at this point that the name of Sarah does not occur in Galatians. Paul refers to her as the "free woman" (eleuthera; v. 22, 23, 30, 31) - a term which is not used about Sarah in the Genesis narrative. On the basis of popular pagan religious views in ancient Anatolia, Elliott (2003:258-266) argues that by not naming Sarah, Paul wants to avoid any parallel between Hagar and Sarah as goddesses. According to Elliott, the addressees may have thought of Hagar as a mountain goddess ("mountain mother"), whereas Paul does not want them to think of Sarah, too, as a mountain goddess (that is why even no mountain is mentioned by Paul in connection with Sarah).

Although I am not convinced by the overall thesis of Elliott, I think she rightly observes that Sarah is rather "defined in relation to Abraham ... and in relation to God" (Elliot, 2003:265). In my opinion, it is not the person of Sarah that is important for Paul, but that which Sarah represents: the relationship with God, based on God's promises. In the argument of Paul, also her status is important, because it highlights the contrast between the (real) slave status of Hagar, who is repeatedly referred to as paidiskē (v. 22, 23, 30 (twice), and 31), and the "free" wife of Abraham, who bore him the child who was expected on the basis of a promise. Scripture, e.g. in Galatians 3:10, 13. For a discussion of these latter quotations, see Davis (2002: esp. 29 ff. and 83 ff.) and Wakefield (2003). 
It may be significant, however, that Hagar is mentioned by name in the Pauline passage (v. 24, 25). Her name is used to highlight the paradox that those Jews in "the present Jerusalem" who do not accept that the promises were fulfilled in Jesus, are as if they were the (spiritual) descendants of Hagar, because they are like slaves in a figurative sense.

We may add that in Genesis 21:10 the two sons are mentioned together: "So she (Sarah) said to Abraham, 'Cast out this slave woman with her son, for the son of this slave woman shall not inherit along with my son Isaac'." However, here they are not specifically referred to as the sons of Abraham; rather, Sarah emphasises that Isaac is her son. It is this very verse which will be quoted by Paul in Galatians 4:30. However, Paul changes the end of the quotation: instead of Sarah's reference to herself and Isaac as her own son, Paul refers to Sarah as the "free woman".

\subsubsection{The antithesis between the slave and the free}

In Galatians 4:23 Paul signals the reason why he refers to the Hagar story when he sets up an antithesis between the one "of the slave" (ek tēs paidiskēs) who was born "according to the flesh" (kata sarka), and the one "of the free woman" who "was born through the promise". It is significant that Isaac was also a son of Abraham kata sarka, so Paul must mean that Ishmael was born to Abraham only "according to the flesh". With Isaac it was more important that he was born on the basis of a promise (cf. Gen. 17:16; 21:12) ${ }^{11}$ than his human, fleshly origin (which is expressed in the NIV's translation of kata sarka as "in the ordinary way"). By this antithesis Paul prepares the way for his using the Hagar story not only as a historical event, but as a story that has a message for the future (including Paul's own day). God is shown here as a God who bases his relationship with his people on promises. Based on this Old Testament story, Paul claims later in the Hagar passage that only those are God's people who trust in his promises. In verse 28 he writes to his Galatian converts: "Now you, my friends, are children of the promise, like Isaac." Thus the idea of "promise" prepares the way for the theme of the "covenant" in verse 24.

In verse 24 Paul refers back to what he has just said, and indeed to the whole Hagar story, because he changes the gender. In verse 23

11 See also Bruce (1982:219). 
Paul refers to the two women (as the "slave woman" and the "free woman"), with a feminine noun and a feminine adjective with a definite article as if with the sense of a noun, respectively, and to their children by the definite article in the masculine nominative (ho). In verse 24 Paul uses the emphatic relative pronoun hatina, a neuter plural nominative form. In the Greek we read: hatina estin allēgoroumena ("Now this is an allegory", NRSV - we have already seen Longenecker's translation above), where allēgoroumena, a passive participle, is also in the neuter plural nominative form - and estin is a third person singular verb, required by the neuter plural subjects.

Then in verse 24 the two women are referred to again, as "two covenants": autai (feminine plural) gar eisin dyo diathēkai. The following verses speak about the antithesis between the two, interpreting the Hagar story in an allegorical way. In these antithetical pairs the application reaches Paul's own day (the "now", nyn - in the expression "the present Jerusalem" in v. 25), and from the "covenant" motif of verse 24 onward the slavery imagery is used not only in its literal sense but also applied to the relationship between human beings and God. The two sides of the antithesis (or, to use Martyn's (1985:410) expression, "antinomies") are conveniently summarised by James Dunn (1993:244; ammendments - PB):

\begin{tabular}{|l|l|}
\hline Mount Sinai for slavery & Free \\
\hline Hagar & (Sarah understood but not named) \\
\hline the present Jerusalem & the Jerusalem above \\
\hline bearing children in slavery & bearing children of promise (Isaac) \\
\hline according to the flesh & born according to the Spirit \\
\hline
\end{tabular}

In this antithesis, Hagar is brought into relationship with Sinai, 12 although it would be expected that the descendants of Isaac, i.e. the Jewish people are in connection with that mountain as the place of the giving of the Mosaic law. Paul claims that "the present Jerusalem" (referring to the Jewish leaders of his day, and to all those Jews who do not accept that the promises of God were fulfilled in Jesus, the Son of God) is the (spiritual) descendant of Hagar. Hagar is first equated with "Mount Sinai in Arabia" (I accept the reading of NA27), and then it is stated about her that she "corresponds 
(systoikhei) to the present Jerusalem" (v. 25). Elliott (2003:261) argues that Paul's equating Hagar with a mountain "would evoke the familiar image of a Mountain Mother" in an Anatolian audience. Even for someone who does not accept this point, it is significant that Elliott, too, affirms concerning Galatians 4:25 that: "No matter how it is translated, Hagar is identified as a mountain called Sinai that corresponds to the Jewish temple-state of Jerusalem." (Elliot, 2003: 260.)

In Galatians 4:25 the verb douleuō is used in a figurative sense about those who are still "under the law" (see v. 4, 5, 21). 13 They do not see that the Old Testament "law" points forward beyond itself. It contains God's promises which are ("now," in Paul's days) fulfilled in Jesus. Those who do not accept Jesus as God's Son, are still "under the law"; the "present" Jerusalem "is in slavery (douleuei) with her children".

In verse 26 Paul contrasts the "above" Jerusalem with the "present" Jerusalem of verse 25 . Bruce (1982:220) rightly notes that the Greek name used here for the city (Ierousalēm) emphasises the "religious significance of the city", whereas the form of the name used in Galatians 1:17 ff. and 2:1 (Hierosolyma) "has the geographical site in view". I can also agree with Longenecker (1990: 213) who affirms that in Galatians 4:25 Paul's "emphasis is on the religious significance of the city: the present city of Jerusalem to which the Judaizers looked as the source and support of their gospel". In the same context Longenecker (1990:213) observes that the Greek form lerousalēm "is the Hebraic and LXX name used often with sacred connotations". In Galatians 4:26 Paul says that the "above" Jerusalem is "free" (eleuthera), thus she is referred to in the same way as Sarah is referred to in the Hagar allegory (without Sarah's proper name being mentioned). Thus the contrast is between those who live only on the basis of the "law", and those who believe in God's promises - these promises now being fulfilled in his Son (as we have seen in v. 4-7).

13 I cannot substantiate this point in this article in further detail; I shall attempt to do that in a commentary on Galatians I am working on. I simply affirm that I hold that the letter is against the view that the Galatian Christians, who are of nonJewish origin, should be circumcised (see e.g. Thielman, 1989). 


\subsubsection{The quotation from Isaiah 54:1}

Paul substantiates his argument with another Old Testament passage, introduced by gegraptai gar. Paul quotes Isaiah 54:1 from the LXX (cf. Silva, 2007:808-809), a passage originally written about the Jewish people in exile, promising them a greater flourishing after the exile than they had experienced before it. In Paul, the two parts of the comparison are probably the Galatian Christians (the spiritual children of the above Jerusalem, believing in God's promises pointing to Jesus) and the Jews who only observe the law without accepting God's promises fulfilled in Jesus. The way Paul applies an Old Testament text that originally referred to God's one and only people to the spiritual people of God (of non-Jewish origin) strengthens our interpretation of the Hagar allegory. Since this quotation is not directly related to Hagar, 14 I turn to the concluding verses of the Hagar allegory where Paul applies the Hagar story to the Galatians with a further quotation from the original Hagar story in the book of Genesis.

\subsubsection{The Galatian Christians in the lineage of Isaac}

In verse 28 Paul addresses his Galatian readers directly (I accept the second person plural reading, hymeis este, with NA27; see also Rohde, 1989:202): "Now you, my friends, are children of the promise, like Isaac." The Galatian Christians, who are of non-Jewish origin, are in the lineage of Isaac. The Greek expression, kata Isaak, we may translate as "after the manner of Isaac". I can agree with Witherington (2004:336) who argues that by this term Paul may also have wanted "to stress that the Galatians came to receive the promise and the inheritance in the same miraculous fashion as Isaac had - by divine intervention".

The Galatian Christians are connected to Isaac through their belief in God's promises (concerning his Son, fulfilled in Jesus). This is of course not a "real" descension, but one that is based on their faith in Jesus. Accordingly, the nyn of verse 29 corresponds to the nyn of v. 25 ("present Jerusalem"). Those who do not believe that Jesus' saving sacrifice is the basis of true relationship with God, are "according to the flesh" and not "according to the Spirit" (v. 29). They persecute those who underwent the experience that the Spirit

14 For an exegesis of the quotation of Isaiah 54:1 in Galatians 4:27, see Silva (2007:808-809), who also points to further literature (see his references to Boer, Willits \& Di Mattei on p. 809). 
convinced them that faith in Jesus is the only means by which to attain a right relationship with God (see Gal. 3:1-5; 5:5-6).

We may note that the idea of persecution is not expressed in the Old Testament narrative concerning the relationship between Ishmael and Isaac; it appeared, however, in the course of the rabbinic exposition of Genesis 21:9.15 Paul may have taken the Hebrew term for playing (tsahaq in the pi'el participial form; see e.g. NRSV) in Genesis 21:9 as referring to a kind of "mocking" (see e.g. NIV).

In Galatians 4:30 Paul quotes Genesis 21:10 (and changes it slightly, as we have seen above): "But what does the Scripture say? 'Drive out the slave and her child; for the child of the slave will not share the inheritance with the child of the free woman'." Here he may refer to the adversaries, and call upon the Galatians to separate themselves from them. Vouga (1998:118-119) rightly emphasises that when Paul quotes the Old Testament text without any comment, he uses it as an admonition valid in his own time.

The verb klēronomēsei ("will share the inheritance") echoes the klēronomos ("heir") of verses 1 and 7 at the beginning of the chapter, thereby reminding the Galatian addressees of their heritage waiting for them as "sons" for the sake of the one "Son", Jesus. 16

In verse 30 , the quotation refers to the "real" slave, Hagar, but it is applied to those who are "slaves" in a spiritual ("metaphorical") sense, because they belong to the lineage of Hagar (because they do not believe in God's promises concerning his Son). Paul's addition to the quotation is his own word for Sarah, "the free woman". $\mathrm{He}$ repeats the same word (eleutheras, in the genitive) in the concluding verse of the Hagar allegory, where he uses "slave" in the figurative sense (v. 31): "So then, friends, we are children, not of the slave but of the free woman." Here Paul uses the first person plural esmen ("we are") referring to the one "new covenant" people of God, consisting of all those who accept God's promises as fulfilled in Jesus, including the Christ-believing (originally non-Jewish) Galatians and himself (as all other Jews who accepted Jesus as the Christ). e.g. Rohde (1989:203-204).

For the related themes of sonship and heritage, see Hodge (2007). 


\section{Concluding remarks}

In conclusion, I summarise some points that Paul expected the Galatians to understand on the basis of what he said and how he said it in the Hagar allegory.

Scripture is authoritative, and the Galatians should read and understand the Old Testament Scripture as God's message pointing forward to the fulfilment of God's promises. Those fulfilments cannot only be found in the Old Testament itself, but in two "covenants". The new covenant claims that God's promises concerning his Son are fulfilled in Jesus. Faith in Him is the only way in which people can have a right relationship with God. This right relationship can be described as sonship, and therefore as being "free".

The opposite is true for those who do not believe God's promises concerning his Son being fulfilled in Jesus. They are like "slaves". Paul uses this well-known expression of his society in two ways: in its literal sense, referring to Hagar, the slave of Abraham; and in a figurative sense, referring to those who do not accept God's promises concerning the new covenant.

Thus slavery imagery is used to convey spiritual messages about how one can belong to God's people in the new covenant. Speaking about "two covenants" entails a view concerning the history of God's relationship with his people, the "fullness" of that history being the time when God has sent his Son (see Gal. 4:4). Slavery imagery describes what one should avoid, and it serves as a contrast to a relationship with God based on trust in his promises. The Hagar story in Galatians 4 is an allegory in the sense that "it is being interpreted" by Paul, who uses it to speak about God's "two covenants".

\section{List of references}

BAUER, W. 1979. A Greek-English lexicon of the New Testament and other early Christian literature. 2nd ed. Transl. by W.F. Arndt \& F.W. Gingrich. Chicago: University of Chicago Press.

BETZ, H.D. 1988. Galatians: a commentary on Paul's letter to the churches in Galatia. Philadelphia: Fortress.

BRUCE, F.F. 1982. The epistle of Paul to the Galatians: a commentary on the Greek text. Exeter: Paternoster.

CARSON, D.A. \& MOO, D.J. 2005. An introduction to the New Testament. 2nd ed. Grand Rapids: Zondervan.

DAVIS, B.S. 2002. Christ as devotio: the argument of Galatians 3:1-14. New York: University Press of America.

DUNN, J.D.G. 1993. The epistle to the Galatians. Peabody: Hendrickson. 
ELLIOTT, S. 2003. Cutting too close for comfort: Paul's letter to the Galatians in its Anatolian cultic context. London: Clark International.

HAYS, R.B. 2000. The letter to the Galatians: introduction, commentary, and reflections. (In Keck, L.E., ed. The new interpreter's Bible. Vol. 11. Nashville: Abingdon. p. 181-348.)

HODGE, C.E.J. 2007. If sons, then heirs: a study of kinship and ethnicity in the letters of Paul. Oxford: Oxford University Press.

LONGENECKER, R.N. 1990. Galatians. Dallas: Word Books.

MARTYN, J.L. 1985. Apocalyptic antinomies in Paul's letter to the Galatians. New Testament studies, 31(3):410-424.

MARTYN, J.L. 1997. Galatians: a new translation with introduction and commentary. New York: Doubleday.

MORRIS, L. 1996. Galatians: Paul's charter of Christian freedom. Downers Grove: InterVarsity.

NANOS, M.D., ed. 2002a. The Galatians debate: contemporary issues in rhetorical and historical interpretation. Peabody: Hendrickson.

NANOS, M.D. 2002b. The irony of Galatians: Paul's letter in first-century context. Minneapolis: Fortress.

ROHDE, J. 1989. Der Brief des Paulus an die Galater. 1. Auflage der Neubearbeitung. Berlin: Evangelische Verlagsanstalt.

SILVA, M. 2007. Galatians. (In Beale, G.K. \& Carson, D.A., eds. Commentary on the New Testament use of the Old Testament. Grand Rapids: Baker Academic. p. 785-812.)

THIELMAN, F. 1989. From plight to solution: a Jewish framework for understanding Paul's view of the law in Galatians and Romans. Leiden: Brill.

VOUGA, F. 1998. An die Galater. Tübingen: Mohr Siebeck.

WAKEFIELD, A.H. 2003. Where to live: the hermeneutical significance of Paul's citations from Scripture in Galatians 3:1-14. Atlanta: Society of Biblical Literature.

WITHERINGTON III, B. 2004. Grace in Galatia: a commentary on Paul's letter to the Galatians. London: Clark International.

YARBROUGH, R.W. 2004. The salvation historical fallacy? Reassessing the history of New Testament theology. Leiden: Deo Publishing.

\section{Key concepts:}

God's promises

Hagar allegory

slavery imagery

two covenants

\section{Kernbegrippe:}

God se beloftes

Hagar-allegorie

slawernybeeld

twee verbonde 